\title{
STUDIES OF THE ACUTE RENAL EFFECTS OF HEMOLYZED RED BLOOD CELLS IN DOGS INCLUDING ESTIMATIONS OF RENAL BLOOD FLOW WITH KRYPTON ${ }^{85} *$
}

\author{
By MARTIN GOLDBERG \\ (From the Chemical Section, Department of Medicine, University of Pennsylvania School of \\ Medicine, Philadelphia, Pa.)
}

(Submitted for publication April 19, 1962; accepted August 9, 1962)

Many investigators have attempted to produce experimental acute renal failure by the administration of hemolyzed red blood cells or the products of hemolysis. Almost all of the successful attempts have required the preliminary preparation of the experimental animal by marked alteration of renal hemodynamics in association with systemic hypotension (1), severe dehydration $(1,2)$, or occlusion of the renal artery $(3,4)$. In other studies renal failure was produced by the administration of massive doses of hemoglobin (5), methemoglobin $(2,6)$, or heterologous blood $(7)$. In all of these situations, it was not possible to differentiate between the specific renal effects of the administered substances and the hemodynamic changes secondary to the alterations in systemic circulation.

Studies in man (8-11) and dogs (12) involving the administration of distilled water, autologous hemolyzed cells, or hemoglobin have suggested that renal ischemia was acutely produced by the administered substances. Because of these experiments, it has become generally accepted that decreased renal blood flow (RBF) is important in the pathogenesis of acute renal failure resulting from intravascular hemolysis. In these studies (8-12), however, the clearance of paraaminohippurate (PAH) was taken to indicate effective renal plasma flow (RPF) even during oliguria.

The present series of experiments was undertaken to evaluate the acute changes in renal function secondary to the administration of homologous hemolyzed red blood cells with the following

\footnotetext{
* Supported in part by U. S. Public Health Service Grant H-340 and in part by the C. Mahlon Kline fund for the development of the Department of Medicine. This work was presented in part before the meeting of the Eastern Section of the American Federation for Clinical Research in Philadelphia, Pa., January 11, 1962.
}

modifications of previous techniques. 1) $\mathrm{RBF}_{\mathrm{Kr}}$ was estimated by an indirect Fick gas diffusion method $(13,14)$ using krypton ${ }^{85}(15,16)$ and not involving the collection of urine, thereby providing a measure of renal hemodynamics independent of the clearance and direct Fick-PAH techniques previously used. Also, in contrast to direct methods of measuring $\mathrm{RBF}$, surgical manipulation of the renal pedicle is not involved. This method is particularly adaptable to the anuric subject $(14,16)$. 2) To circumvent many of the problems previously encountered in regard to systemic changes, moderate quantities of hemolysate ( 0.2 to $0.3 \mathrm{~g}$ hemoglobin per $\mathrm{kg}$ body weight) were infused into the aorta just above the renal arteries. Hypotension, severe dehydration, and acidosis were avoided. This procedure minimized systemic effects and obviated the necessity for the administration of massive doses.

The results of these experiments are interpreted as indicating that an acute reduction in urine flow (V) and decreased clearances of various substances can occur without either generalized renal ischemia or diminished renal extraction of these substances; the data suggest that acute intratubular obstruction may be an important factor in the oliguria associated with the excretion of blood pigments.

\section{METHODS}

Experiments were performed on 12 female mongrel dogs weighing 17 to $26 \mathrm{~kg}$ on standard animal colony diets. Before each experiment, food was withheld for 12 hours, but water was allowed freely. The animals were lightly anesthetized with intravenous pentobarbital sodium. An intravenous infusion of 5 per cent glucose in water was started at the beginning of each experiment. In order to vary the rates of urine flow during the control periods $\left(V_{c}\right)$ in the different dogs, the rate of infusion of glucose in water was made different for each dog, but in each individual experiment the rate was kept constant throughout the procedure. 
A no. 7 or 8 curve-tipped, radio-opaque, venous catheter was passed under fluoroscopic guidance from the external jugular vein deep into the left renal vein. An identical catheter was passed from the femoral artery into the descending aorta above the renal vessels, i.e., above the level of the catheter in the renal vein. Both catheters were connected to manifold systems consisting of six three-way stopcocks used for withdrawing arterial and renal venous blood. The positions of the catheters were verified at autopsy in the 9 dogs that were sacrificed immediately after the acute experiments.

Hemolyzed canine red blood cells were prepared as follows. Whole blood was obtained from a donor dog, and the packed cells were separated from the plasma by centrifugation. The cells were added to 1.5 times their volume of distilled water. After hemolysis and filtration through gauze, the filtrate was made isotonic by the addition of an appropriate quantity of sodium chloride and the $\mathrm{pH}$ was adjusted to 7.4 with sodium hydroxide. The hemolysate was prepared on the day of the experiment just before its administration.

After the collection of three control urine periods of 15 to 30 minutes each during which the rate of $V_{c}$ was apparently stable, the hemolysate was administered through the catheter in the aorta in a dosage of 0.2 to $0.3 \mathrm{~g}$ hemoglobin per $\mathrm{kg}$ body weight over a period of 1 to 3 minutes, and the effects were observed for at least 2 hours after in the infusion.

The clearances $(C)$ and renal extraction ratios (E) of exogenous creatinine, hippuran labeled with $\mathrm{I}^{131}$ (Radiohippuran ${ }^{1}$ ), and PAH were determined by standard techniques. Both priming doses and constant sustaining infusions were given so that the approximate blood levels were 6 to $8 \mathrm{mg}$ per $100 \mathrm{ml}$ for creatinine, 2,000 counts per minute per $\mathrm{ml}$ for Radio-hippuran, and 2 to $4 \mathrm{mg}$ per 100 $\mathrm{ml}$ for PAH. Arterial blood was drawn in heparinized syringes at the midpoint of the clearance periods. Plasma was separated from the cells by centrifugation immediately after collection. Creatinine was estimated in blood and urine by the method of Bonsnes and Taussky (17), PAH by the method of Smith and colleagues (18), and the concentration of Radio-hippuran in plasma and urine was determined by counting $1-\mathrm{ml}$ samples in a scintillation well counter.

Percentage of oxygen saturation of arterial and renal venous whole blood samples was determined by an oximetric technique using a Waters oximeter, and the oxygen content was calculated from the oxygen saturation and the hemoglobin concentration. Whole blood arterial $\mathrm{pH}$ was determined anaerobically with a glass electrode Beckman $\mathrm{pH}$ meter, and the mean arterial blood pressure was measured with a mercury manometer attached to the aortic catheter.

Renal blood flow by the gas diffusion method. The indirect Fick inert gas method was first developed by Kety and Schmidt (13) to study cerebral blood flow with nitrous oxide. The procedure used in the present study is a modification of the methods of Conn, Anderson, and

${ }^{1}$ Kindly supplied by Abbott Laboratories, Chicago, Ill.
Arena (14), who used nitrous oxide to study $R B F$ in dogs, and of Brun and co-workers (15) and Munck (16), who substituted the radioactive inert gas krypton ${ }^{85}$ to facilitate analyses of the specimens and improve the accuracy of the method.

The apparatus for administering the radioactive gas consisted of a 60-liter Douglas bag containing 25 per cent oxygen, 75 per cent nitrogen, and approximately $6 \mathrm{mc}$ of krypton ${ }^{85}$, predominantly an intermediate-energy beta-ray emitter with a half-life of 10.3 years. The bag was connected to a closed circle system containing a sodalime $\mathrm{CO}_{2}$ absorber and a motor blower. The system was connected by a three-way respiratory valve to an endotracheal tube in the animal.

The arterial and renal venous manifold systems each contained six oiled and heparinized syringes and one exhaust syringe. The dead space of the system was filled with a dilute solution of heparin. During a blood flow study, six integrated simultaneous arterial and renal venous samples were collected, each at a rate of $0.4 \mathrm{ml}$ per 3 seconds. The first three samples were collected in succession 0 to 30,30 to 60 , and 60 to 90 seconds after clearing the dead space, and the last three were collected from 120 to 150 seconds, 198 to 228 seconds, and 282 to 312 seconds, respectively.

Each specimen containing krypton ${ }^{85}$ was analyzed by a count of the beta emissions after the loading of specially designed planchets. These stainless steel, disk-shaped planchets had on both sides a circular Mylar window 1 inch in diameter and 0.0005 inch in thickness. The loaded planchet was placed in a fixed receptacle on a stainless steel stage containing two end-window Geiger-Müller tubes such that each tube received the emissions through each Mylar window on the planchet. The tubes were connected in parallel to a counter so that the sum of the radioactive emissions received by the two tubes was recorded. The planchets, each with a volume of $2.5 \mathrm{ml}$, had Luer connections that could be closed anaerobically after loading from the syringe. The stage with the Geiger-Müller tubes and planchet receptacle was constructed to provide reproducible geometry for all specimens. This system provided 1,100 to 1,500 counts per minute from the most active specimens. It was found that there was no loss of radioactivity from the planchets in specimens re-counted at intervals up to 2 hours after the initial loading.

In all of the animals studied, tissue: blood equilibrium was reached at or before 5 minutes of inhalation, so there was no need to collect specimens after 5 minutes. The results were plotted on co-ordinate graph paper with counts per minute per specimen on the ordinate and time in minutes on the abcissa; representative curves are shown in Figures 1 and 2. RBF in $\mathrm{ml}$. per $100 \mathrm{~g}$ per minute was calculated by the modified formula of Brun and colleagues (15):

$$
\mathrm{RBF}_{\mathrm{Kr}}=100 \cdot R^{t} \cdot S / \int_{0}^{t}(A-R) d t-T R^{t} .
$$

$R^{t}=$ renal venous concentration of the gas at tissue :blood equilibrium at time $t$. $S=$ partition coefficient for kryp- 
ton between kidney and blood, here assumed to be 1 (15, 16). However, since the experiments are principally concerned with changes in flow, the absolute value of $S$ is not of critical importance provided it does not change during any one experiment. $\int_{0}^{t}(A-R) d t=$ the area between the arterial and venous curves from time 0 until equilibrium, $t$. This was determined from the curves by the rule of trapezoids or by planimetry. $T=$ time lag between arterial and venous curve, assumed to be 0.05 minutes.

$\mathrm{RBF}_{\mathrm{Kr}}$ was determined in 7 dogs during one of the three control (preinfusion) periods and 30 to $120 \mathrm{~min}$ utes after the infusion of hemolysate (postinfusion), usually during the time of minimal V. In dog 14 only a control value was obtained, since the postinfusion specimens were contaminated with air. The renal oxygen consumption ( $\mathrm{Q}_{\mathrm{o}_{2}}$ ) expressed as $\mathrm{ml}$ per $100 \mathrm{~g}$ per minute was calculated from the $\mathrm{RBF}_{\mathrm{Kr}}$ and the renal arteriovenous oxygen difference $\left[(A-R) O_{2}\right]$.

Nine dogs were sacrificed immediately after the acute experiment. Dogs 7, 8, and 9 were sacrificed 12, 16, and 110 hours, respectively, after conclusion of the acute experiment. An autopsy was performed on each animal, and microscopic sections of the kidneys stained with hematoxylin and eosin and with alizarin red were prepared and examined.

\section{RESULTS}

Effects on $V$, clearances of creatinine $\left(C_{c r}\right)$ and Radio-hippuran $\left(C_{\text {hipp }}\right)$, mean arterial blood pressure, and arterial $p H$. The protocol of a representative experiment, on $\operatorname{dog} 7$, illustrating a marked decrease in $\mathrm{V}$ and $\mathrm{C}_{\mathrm{cr}}$ in response to the
TABLE I

Protocol of a representative experiment on $\operatorname{dog} 7$, illustrating marked decrease in urine flow and creatinine clearance without a corrsponding fall in renal blood flow *

\begin{tabular}{|c|c|c|c|c|c|}
\hline $\begin{array}{c}\text { Elapsed } \\
\text { time }\end{array}$ & $\mathrm{v}$ & $\mathrm{C}_{\mathrm{er}}$ & $\begin{array}{l}\text { Mean } \\
\text { blood } \\
\text { pressure }\end{array}$ & $\mathrm{RBF}_{\mathrm{Kr}}$ & $\begin{array}{c}\text { Arterial } \\
\mathrm{pH}\end{array}$ \\
\hline $\min$ & & $\mathrm{ml} / \mathrm{min}$ & $m m \mathrm{Hg}$ & $\begin{array}{c}m l / 100 \\
g / m i n\end{array}$ & \\
\hline-60 to 0 & \multicolumn{5}{|c|}{$\begin{array}{l}\text { Priming dose of creatinine given, and sus- } \\
\text { taining infusion started and maintained at } \\
\text { a constant rate throughout experiment. }\end{array}$} \\
\hline 0 to 21 & 1.33 & 83.8 & 138 & & \\
\hline 21 to 40 & 1.74 & 73.6 & 124 & 239 & \\
\hline 40 to 55 & 1.53 & 66.1 & 120 & & 7.40 \\
\hline 55 to 57 & \multicolumn{5}{|c|}{$\begin{array}{l}\text { Infusion of } 5 \mathrm{~g} \text { hemoblobin }(0.21 \mathrm{~g} \text { per } \mathrm{kg}) \\
\text { as hemolyzed red blood cells into aorta } \\
(\mathrm{pH}=7.40) \text {. }\end{array}$} \\
\hline 55 to 71 & 0.21 & 12.1 & 135 & & 7.40 \\
\hline 71 to 93 & 0.11 & 21.4 & 130 & 265 & \\
\hline 93 to 140 & 0.046 & 10.6 & 125 & & \\
\hline
\end{tabular}

*Abbreviations: $\mathrm{V}=$ urine flow, $\mathrm{C}_{\mathrm{er}}=$ creatinine clearance, and $\mathrm{RBF}_{\mathrm{Kr}}=$ renal blood flow, as measured by indirect Fick method with krypton ${ }^{85}$.

infusion of hemolysate is shown in Table $\mathrm{I}$, and the fractional changes in $\mathrm{V}$ and $\mathrm{C}_{\mathrm{rr}}$ in 12 dogs and $\mathrm{C}_{\text {hipp }}$ in 6 dogs are summarized in Table II. These data illustrate the acute changes occurring during the postinfusion periods up to 2 hours after the infusion of hemolyzed cells. In every animal there was a marked diminution in $\mathrm{V}$ varying from 50 to 95 per cent, and in 11 of the 12 dogs there occurred a decrease in $C_{\mathrm{cr}}$ varying from 6 to 99

TABLE II

Effects on urine flow, creatinine clearance, Radio-hippuran clearance, mean arterial blood pressure and arterial $p H^{*}$

\begin{tabular}{|c|c|c|c|c|c|c|c|c|c|c|}
\hline \multirow[b]{3}{*}{ Dog } & \multicolumn{5}{|c|}{ Control $\dagger$} & \multicolumn{5}{|c|}{ Postinfusion $\ddagger$} \\
\hline & \multirow[b]{2}{*}{$\mathrm{V}$} & \multirow[b]{2}{*}{$\mathrm{C}_{\mathrm{er}}$} & \multirow[b]{2}{*}{$\mathrm{C}_{\text {hipp }}$} & \multirow{2}{*}{$\begin{array}{l}\text { Mean } \\
\text { blood } \\
\text { pressure }\end{array}$} & \multirow[b]{2}{*}{$\mathrm{pH}$} & \multicolumn{3}{|c|}{ Fractional changes $\S$} & \multirow{2}{*}{$\begin{array}{l}\text { Mean } \\
\text { blood } \\
\text { pressure }\end{array}$} & \multirow[b]{2}{*}{$\mathrm{pH}$} \\
\hline & & & & & & V & Cor & $\mathrm{C}_{\text {hipp }}$ & & \\
\hline & $m l / \min$ & $m l / m i n$ & $m l / m i n$ & $m m H g$ & & & & & $m m H g$ & \\
\hline 5 & 0.47 & 86.4 & & 110 & & -0.93 & -0.99 & & 120 & \\
\hline 6 & 0.51 & 65.6 & & 135 & & -0.92 & -0.98 & & 138 & \\
\hline 7 & 1.53 & 74.5 & & 120 & 7.40 & -0.95 & -0.78 & & 134 & 7.40 \\
\hline 8 & 1.44 & 68.9 & & 145 & 7.40 & -0.66 & -0.21 & & 148 & 7.40 \\
\hline 9 & 1.41 & 72.2 & & 132 & 7.40 & -0.85 & -0.26 & & 144 & 7.39 \\
\hline 10 & 6.29 & 92.4 & & 145 & 7.39 & -0.50 & +0.02 & & 138 & 7.32 \\
\hline 11 & 0.21 & 23.1 & 96.4 & 100 & & -0.87 & -0.90 & -0.90 & 125 & \\
\hline 12 & 3.67 & 112.0 & 211 & 144 & & -0.63 & -0.18 & -0.29 & 140 & \\
\hline 13 & 0.61 & 86.3 & 138 & 143 & 7.39 & -0.51 & -0.06 & -0.16 & 130 & 7.40 \\
\hline 14 & 0.80 & 39.9 & 177 & 100 & 7.40 & -0.65 & -0.54 & -0.38 & 107 & \\
\hline 15 & 1.96 & 77.7 & 155 & 130 & 7.36 & -0.77 & -0.17 & -0.32 & 122 & \\
\hline 19 & 1.49 & 67.8 & 82.6 & 115 & & -0.73 & -0.18 & -0.27 & 109 & \\
\hline & & $\begin{array}{l}72.2 \\
22.4\end{array}$ & $\begin{array}{c}149 \\
38.1\end{array}$ & $\begin{array}{c}127 \\
16.3\end{array}$ & & $\begin{array}{r}-0.75 \\
0.15\end{array}$ & $\begin{array}{r}-0.44 \\
0.36\end{array}$ & $\begin{array}{r}-0.39 \\
0.24\end{array}$ & $\begin{array}{l}130 \\
12.5\end{array}$ & \\
\hline
\end{tabular}

* Abbreviations as in Table $\mathrm{I}$, and $\mathrm{C}_{\mathrm{hipp}}=$ Radio-hippuran clearance.

Data are means of 3 periods. weight).

$\$$ Fractional change $=$ experimental change in a variable $\Delta \mathrm{X}$ divided by the control value for that variable $\mathrm{X}_{\mathrm{c}}$. 
per cent. The postinfusion values for these variables are significantly different from the control values; for $\mathrm{V}, \mathrm{SE}$ of the mean difference $=0.254$, $\mathrm{p}<0.001$, and $\mathrm{SE}$ of the mean difference $=8.17$, $\mathrm{p}<0.005$ for $\mathrm{C}_{\text {cr }}$. Changes in $\mathrm{C}_{\text {hipp }}$ paralleled the changes in $\mathrm{C}_{\mathrm{er}} ; \mathrm{SE}$ of the mean difference $=9.74$, $p<0.005$. For reasons to be discussed, neither the changes in $\mathrm{C}_{\mathrm{cr}}$ nor $\mathrm{C}_{\text {hipp }}$ are believed to reflect accurately changes in glomerular filtration rate (GFR) or effective RPF. These changes in flow and clearance occurred without hypotension or consistent elevations in mean arterial blood pressure, and the infusions did not appear to affect arterial $\mathrm{pH}$.

Since there was a variation in the degree of decrease in $\mathrm{C}_{\mathrm{er}}$ and $\mathrm{V}$ after the infusion, an attempt was made to see if there was any relationship between the fractional changes in these variables, $\Delta V / V_{c}$ and $\Delta C_{c r} / C_{e_{c}}$, and several control observations. No statistical correlation was demonstrable between $\Delta \mathrm{V} / \mathrm{V}_{\mathrm{c}}$ or $\Delta \mathrm{C}_{\mathrm{cr}} / \mathrm{C}_{\mathrm{cr}_{\mathrm{c}}}$ and the control or preinfusion GFR or RBF. However, using rank correlation, a nonparametric method independent of a normal distribution of both variates (19), a relationship between $\Delta C_{\mathrm{er}} / \mathrm{C}_{\mathrm{er}_{\mathrm{c}}}$ and $\mathrm{V}_{\mathrm{c}}$ was present $; \mathrm{r}_{\mathrm{s}}=-0.71$, significant at the 1 per cent level. Since this is a negative correlation, the relationship is such that the lower $V_{c}$, the greater the degree of diminution of $\mathrm{C}_{\mathrm{cr}}$ after the infusion. A questionable rank correlation was present between $\Delta V / V_{c}$ and $V_{c} ; r_{s}=-0.45$, not significant at the 5 per cent level.

Included in the above calculations are the data from $\operatorname{dog} 13$, which appeared to respond to the infusion of the hemolysate differently from the other animals. Despite a very low $V_{c}$ of $0.61 \mathrm{ml}$ per minute, the fractional change in $\mathrm{V}$ was the lowest of the group, at -0.51 , and the fractional change in $C_{\mathrm{cr}}$ was only -0.06 . The most striking difference, however, was the rise in $\mathrm{RBF}_{\mathrm{Kr}}$ in this animal from 265 to $485 \mathrm{ml}$ per $100 \mathrm{~g}$ per minute (Table III). This is almost three times the 15 per cent variation inherent in the method itself at flows in this range (16). The cause of this rise in $\mathrm{RBF}_{\mathbf{K r}}$ is not apparent from the experimental protocol, although an undetected pyrogenic reaction might explain it.

Effects on $R B F_{K r},(A-R) O_{2}$, and $Q_{o_{2}}$. In Table III, the values of the RBF during the control periods obtained simultaneously by the direct Fick (Radio-hippuran, $\mathrm{PAH}$, creatinine) and the indirect Fick (krypton ${ }^{85}$ ) methods in 4 dogs are given. In order to compare the two techniques, the $\mathrm{RBF}_{\mathrm{Kr}}$ in milliliters per 100 grams per minute was multiplied by the weight of both kidneys to give total RBF. Considering the difficulties in making comparisons between these two techniques, such as the potential inaccuracy in assessing the "true" kidney weight at autopsy and the necessity for correcting the direct Fick calculations for diffusion from the red blood cells before separation of the plasma and for trapped plasma in the hematocrit determination, there was a reasonable agreement between the two methods. The ratio direct Fick RBF : indirect Fick RBF varied from 0.98 to 1.25 with a mean of 1.11 .

In the postinfusion periods, however, despite the uniform decrease in $\mathrm{C}_{\mathrm{er}}$ and $\mathrm{C}_{\text {hipp }}$ (Table II),

TABLE III

Comparison of renal blood flow values obtained simultaneously by the direct Fick and indirect Fick (Kr85) methods *

\begin{tabular}{|c|c|c|c|c|c|c|c|}
\hline \multirow{3}{*}{ Dog } & \multicolumn{4}{|c|}{ Direct Fick RBF † } & & & \multirow{3}{*}{$\begin{array}{c}\text { Direct Fick } \\
\mathrm{RBF}(\mathrm{ml} / \mathrm{min}) / \\
\text { indirect Fick } \\
\mathrm{RBF}_{\mathrm{Kr}}(\mathrm{ml} / \mathrm{min})\end{array}$} \\
\hline & \multirow{2}{*}{$\frac{\begin{array}{c}\text { Radio- } \\
\text { hippuran }\end{array}}{\mathrm{ml} / \mathrm{min}}$} & \multirow{2}{*}{$\frac{\mathrm{PAH}}{\mathrm{ml} / \mathrm{min}}$} & \multirow{2}{*}{$\frac{\text { Creatinine }}{m l / m i n}$} & \multirow{2}{*}{$\frac{\text { Mean }}{m l / m i n}$} & \multicolumn{2}{|c|}{$\begin{array}{c}\text { Indirect Fick } \\
\mathbf{R B F}_{\mathbf{K} \mathbf{r}}\end{array}$} & \\
\hline & & & & & $\underset{\mathrm{gl} / \mathrm{min}}{\mathrm{ml}}$ & $m l / m i n$ & \\
\hline $\begin{array}{l}11 \\
13 \\
14 \\
15\end{array}$ & $\begin{array}{l}280 \\
504 \\
752 \\
538\end{array}$ & $\begin{array}{l}688 \\
503\end{array}$ & $\begin{array}{l}295 \\
600 \\
559 \\
498\end{array}$ & $\begin{array}{l}287 \\
552 \\
666 \\
513\end{array}$ & $\begin{array}{l}267 \\
265 \\
380 \\
339\end{array}$ & $\begin{array}{l}294 \\
442 \\
635 \\
437\end{array}$ & $\begin{array}{l}0.98 \\
1.25 \\
1.05 \\
1.17\end{array}$ \\
\hline & & & & & & & 1.11 \\
\hline
\end{tabular}

* Data taken from control (preinfusion) periods.

$\uparrow$ For comparison of the two methods, the extraction ratios of para-aminohippurate and hippuran, $E_{P A B}$ and $E_{h i p p}$. were corrected for diffusion of the substances from the red blood cells before separation of the plasma, and the hematocrits were corrected for trapped plasma $(28)$. $\mathrm{RBF}=\mathrm{C} / 1.05 \mathrm{E}(1-0.95$ hematocrit $)$. 


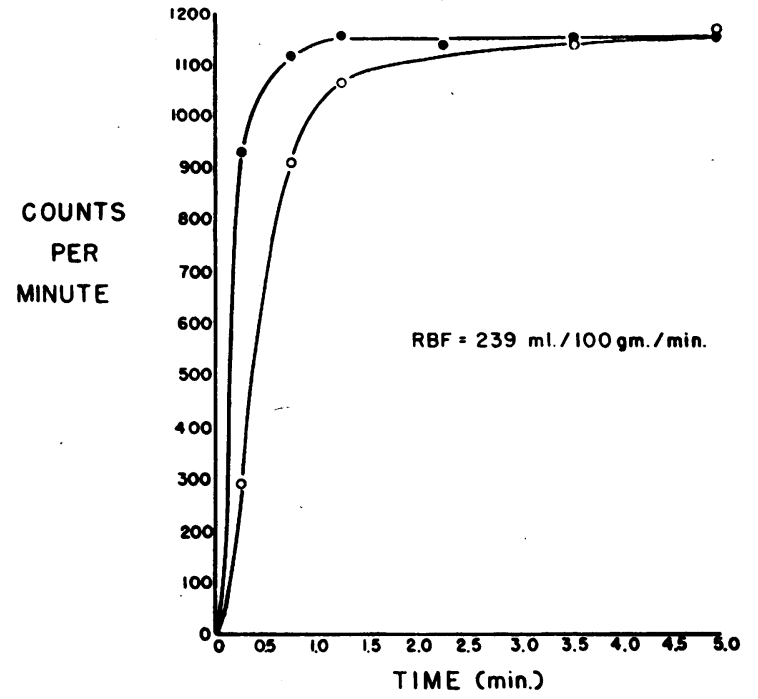

Fig. 1. Curves of Krypton ${ }^{85}$ CONCENtration DURING DETERMINATION OF RENAL BLOOD FLOW BEFORE THE INFUSION OF HEMOLYZED RED BLOOD CELLS IN DOG 7. The upper curve represents the arterial and the lower the venous concentration.

a consistent decrease in $\mathrm{RBF}_{\mathrm{Kr}}$ was not observed. Table $I$ and Figures 1 and 2 illustrate the effects of the infusion on $\mathrm{RBF}_{\mathbf{K r}}$ in an experiment which resulted in severe oliguria. Note the absence of a decrease in $\mathrm{RBF}_{\mathrm{Kr}}$ despite marked changes in $\mathrm{V}$ and $\mathrm{C}_{\mathrm{cr}}$. Table IV summarizes the data from 7 animals in which pre- and postinfusion studies of blood flow were obtained. In an eighth dog (no. 14) only the preinfusion flow is given because the

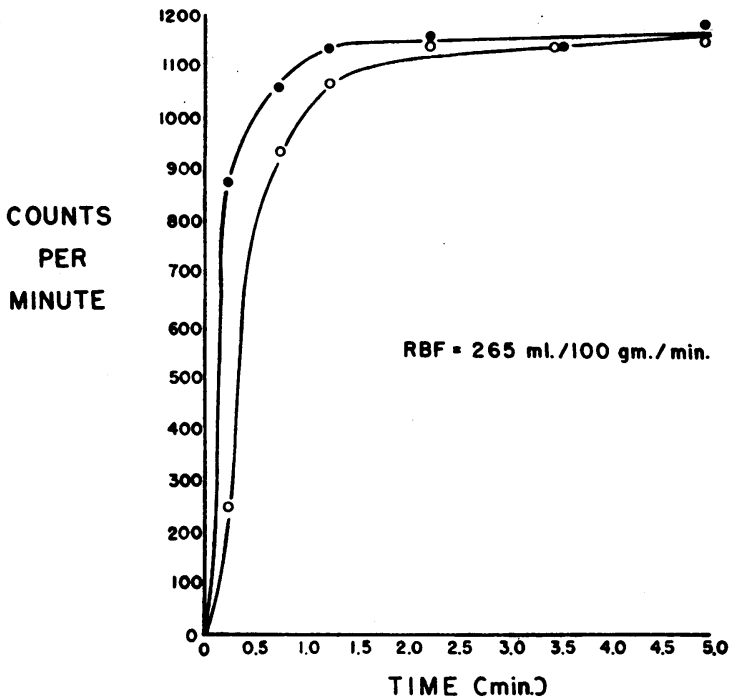

Fig. 2. CuRves OF KRYPTON ${ }^{85}$ CONCENTRATION DURING DETERMINATION OF RENAL BLOOD FLOW AFTER THE INFUSION OF HEMOLYSATE DURING MINIMAL URINE FLOW IN DOG 7 . Note the similarity of these curves to the preinfusion curves in time of attainment of tissue: blood equilibrium and the actual value for blood flow.

postinfusion study was invalidated by contamination of the sampling system with air. These data indicate that neither decreased renal perfusion per unit weight of kidney nor renal hypoxia appeared to result from the infusion of hemolysate, although significant alterations in $\mathrm{V}$ and $\mathrm{C}$ did occur. The postinfusion values of $\mathrm{RBF}_{\mathbf{K r}}$ are not significantly different statistically from the preinfusion values;

TABLE IV

Effects on renal blood flow $\left(K_{r^{85}}\right)$, renal arteriovenous oxygen difference, and oxygen uptake*

\begin{tabular}{|c|c|c|c|c|c|c|c|c|}
\hline \multirow[b]{2}{*}{ Dog } & & \multicolumn{3}{|c|}{ Control $\dagger$} & \multicolumn{4}{|c|}{ Postinfusion $\ddagger$} \\
\hline & & $\mathrm{RBF}_{\mathrm{Kr}}$ & $(A-R) \mathrm{O}_{2}$ & Qo: & $\Delta \mathrm{V} / \mathrm{V}_{\mathrm{c}}$ & $\mathrm{RBF}_{\mathrm{Kr}}$ & $(A-R) \mathrm{O}_{2}$ & $\mathrm{QO}_{2}$ \\
\hline \multirow{13}{*}{$\begin{array}{r}7 \\
8 \\
9 \\
10 \\
11 \\
13 \\
14 \\
15 \\
19\end{array}$} & & $\mathrm{ml}_{\min } / 100 \mathrm{~g} /$ & vol\% & $\underset{\min }{\mathrm{ml} / 100 \mathrm{~g} /}$ & & $\underset{\text { min }}{m l / 100} \mathrm{~g} /$ & vol\% & $\underset{\min }{m l / 100 \mathrm{~g} /}$ \\
\hline & & 239 & & & -0.95 & 265 & & \\
\hline & & 283 & 2.9 & 8.9 & -0.66 & 237 & 2.0 & 4.7 \\
\hline & & 334 & 2.4 & 8.0 & -0.85 & 387 & 2.9 & 11.2 \\
\hline & & 265 & & & -0.50 & 253 & & \\
\hline & & 267 & 3.6 & 9.6 & -0.87 & 253 & 2.5 & 6.3 \\
\hline & & 265 & 2.1 & 5.6 & -0.51 & 485 & 3.0 & 14.5 \\
\hline & & 380 & 1.4 & 5.3 & -0.65 & & 2.0 & \\
\hline & & 339 & & & -0.77 & 427 & & \\
\hline & & & 1.7 & & -0.73 & & 2.1 & \\
\hline & $\mathrm{N}$ & 8 & 6 & 5 & 9 & 7 & 6 & 4 \\
\hline & Mean & 296 & 2.3 & 7.5 & -0.72 & 329 & 2.4 & 9.2 \\
\hline & SD & 14.3 & 0.8 & 1.7 & & 29.6 & 0.5 & 3.8 \\
\hline
\end{tabular}

* Abbreviations as in Table $\mathrm{I}$, and $(A-R) \mathrm{O}_{2}=$ renal arteriovenous oxygen difference, $\mathrm{QO}_{2}=$ renal oxygen consumption, and $\mathrm{V}_{\mathrm{c}}=$ control urine flow.

$\dagger$ Data are means of 3 control urine periods.

$\ddagger$ Data taken during periods of minimal $V$ within 2 hours after infusion of hemolysate. 
SE of the mean difference $=33.8, \mathrm{p}>0.20$. It is difficult to attach any significance to the specific changes in $Q_{0_{2}}$, which rose in 2 animals and fell in 2. Of importance is the absence of a marked reduction of $\mathrm{Q}_{2}$ to extremely low values in the postinfusion period despite marked changes in $\mathrm{V}$ and $\mathrm{C}_{\mathrm{cr}}$ in these animals. All the observed changes in $\mathrm{RBF}_{\mathrm{Kr}}$ were within or close to the 15 per cent variation in the method, except for $\operatorname{dog} 13$, as previously discussed.

Effects on $E_{\text {hipp }}, E_{P_{A} I I}$, and $E_{\text {cr. }}$. Table $\mathrm{V}$ summarizes the changes in $\mathrm{E}_{\mathrm{hipp}}$ and $\mathrm{E}_{\mathrm{cr}}$ studied in five experiments. In 4 of the 5 animals, the changes in $\mathrm{E}_{\mathrm{hipp}}$ were less than 8 per cent, and the mean change for the 5 animals was 9 per cent despite consistent decreases in $\mathrm{V}$ and $\mathrm{C}_{\mathrm{cr}}$ in them. The control values of $E_{\text {hipp }}$ were, in 4 out of 5 animals, close to 0.5 . This relatively low extraction ratio probably explains the lower values for $\mathrm{C}_{\text {hipp }}$ compared to simultaneously determined $\mathrm{C}_{\mathbf{P A H}}$ obtained by others (20). The discrepancy between $\mathrm{C}_{\text {hipp }}$ and $\mathrm{C}_{\mathbf{P A H}}$ does not appear to be adequately explained by contamination with free $\mathrm{I}^{131}$ or red blood cell penetration of hippuran $(20,21)$. In dogs 14,15 , and 19, simultaneously determined values of $E_{\mathbf{P A H}}$ confirm the absence of significant changes in the ability of the tubules to extract hippuric acid derivatives as a result of the infusion of hemolysate.

The mean change in $\mathrm{E}_{\mathrm{cr}}$ in the same 5 dogs was also negligible $(-0.05)$. The greater variation in $\Delta \mathrm{E}_{\mathrm{cr}} / \mathrm{E}_{\mathrm{cr}_{\mathrm{c}}}$ may be due in large part to the errors related to the relatively small arteriovenous dif-

TABLE V

Effects on renal extraction of Radio-hippuran, creatinine, and para-aminohippurate*

\begin{tabular}{|c|c|c|c|c|c|c|c|}
\hline \multirow[b]{3}{*}{ Dog } & & & & \multicolumn{4}{|c|}{ Postinfusion: } \\
\hline & \multicolumn{3}{|c|}{ Control $\dagger$} & \multicolumn{4}{|c|}{ Fractional changes $\S$} \\
\hline & $\mathrm{E}_{\mathrm{hipp}}$ & $E_{\text {er }}$ & EPAH & $\mathrm{V}$ & $\mathrm{E}_{\mathrm{lipp}}$ & $\mathrm{E}_{\text {cr }}$ & EPAH \\
\hline 11 & 0.51 & 0.12 & & -0.87 & -0.50 & -0.55 & \\
\hline 13 & 0.54 & 0.30 & & -0.51 & +0.01 & +0.29 & \\
\hline 14 & 0.53 & 0.17 & 0.73 & -0.65 & -0.05 & -0.06 & -0.15 \\
\hline 15 & 0.46 & 0.26 & 0.73 & -0.77 & +0.02 & +0.36 & +0.11 \\
\hline 19 & 0.29 & 0.19 & 0.76 & -0.73 & +0.07 & -0.28 & +0.04 \\
\hline Mean & 0.47 & 0.21 & 0.74 & -0.71 & -0.09 & -0.05 & $\mathbf{0}$ \\
\hline
\end{tabular}

* Abbreviations as in Tables $\mathrm{I}$ and III, and $\mathrm{E}_{\mathrm{ar}}=$ creatinine extrac tion ratio.

+ Data are means of 3 periods.

I Data are means of 2 to 5 postinfusion periods collected up to 2 o Fractional change hemolysate. $\$$ Fractional change $=$ experimental change in a variable $\Delta \mathrm{X}$ divided
by the control value for that variable $\mathrm{X}_{\mathrm{c}}$.
TABLE VI

lifferts on urine/plasma creatinine, and urine/plasma osmolality

\begin{tabular}{|c|c|c|c|c|c|}
\hline \multirow[b]{2}{*}{ Dog } & & \multicolumn{2}{|c|}{$\mathrm{U} / \mathrm{P}$ creatinine } & \multicolumn{2}{|c|}{$\mathrm{U} / \mathrm{P}$ osmolality* } \\
\hline & & Control & $\begin{array}{c}\text { Post- } \\
\text { infusion }\end{array}$ & Control & $\begin{array}{c}\text { Post- } \\
\text { infusion }\end{array}$ \\
\hline 5 & & 184 & 3.03 & & \\
\hline 6 & & 129 & 35.3 & & \\
\hline 7 & & 48.7 & 205 & 0.478 & 1.28 \\
\hline 8 & & 47.8 & 113 & 0.902 & 1.67 \\
\hline 9 & & 51.2 & 252 & 1.48 & 2.50 \\
\hline 10 & & 14.7 & 30.0 & 0.537 & 0.717 \\
\hline 11 & & 110 & 82.2 & 1.15 & 1.05 \\
\hline 12 & & 30.5 & 68.0 & 0.521 & 0.883 \\
\hline 13 & & 141.0 & 271 & 2.45 & 2.92 \\
\hline 14 & & 49.9 & 66.1 & 1.57 & 1.81 \\
\hline 15 & & 39.6 & 143 & 1.57 & 2.41 \\
\hline \multirow[t]{2}{*}{19} & & 45.5 & 139 & & \\
\hline & $\begin{array}{l}\text { N } \\
\text { Mean } \\
\text { SD }\end{array}$ & $\begin{array}{l}12 \\
74.3 \\
50.6\end{array}$ & $\begin{array}{r}12 \\
117 \\
84.2\end{array}$ & $\begin{array}{l}9 \\
1.18 \\
0.625\end{array}$ & $\begin{array}{l}9 \\
1.69 \\
0.742\end{array}$ \\
\hline
\end{tabular}

* Mean control plasma osmolality $=278$ mOsm per $\mathrm{kg}, \mathrm{SD}=17.4$ mOsm per kg; mean postinfusion plasma osmolality $=278 \mathrm{mOsm}$ per $\mathrm{kg}$. $\mathrm{SD}=13.6 \mathrm{mOsm}$ per $\mathrm{kg}$.

ferences for creatinine. Note, however, that there was a 55 per cent decrease of $E_{\text {cr }}$ in dog 11 together with a 50 per cent decrease in $\mathrm{E}_{\text {hipp. }}$. These latter changes are probably "physiologically" significant, as will be discussed in the following section.

Effects on urine/plasma $(U / P)$ creatinine and $U / P$ osmolality. Table VI summarizes the control and postinfusion values for $\mathrm{U} / \mathrm{P}$ creatinine in 12 animals and $\mathrm{U} / \mathrm{P}$ osmolality in 9 animals. In all animals except dogs 5, 6, and 11, there was a definite rise in the $U / P$ creatinine with a decrease in $\mathrm{V}$, indicating increased renal tubular reabsorption of water. Increases in $\mathrm{U} / \mathrm{P}$ osmolality in 8 of 9 animals reflect the ability of the renal concentrating mechanism to maintain or increase the $\mathrm{U} / \mathrm{P}$ osmotic gradient. Since the postinfusion plasma osmolality does not appear to be different from the control value and since plasma hypertonicity did not result from the infusion, it does not appear that the rise in urine osmolality and decrease in urine flow resulted from an osmotic stimulus for the secretion of vasopressin.

In dogs 5, 6, and 11, however, severe oliguria was associated with significant decreases in $U / P$ creatinine, and the $\mathrm{U} / \mathrm{P}$ osmolality determined in dog 11 showed a decrease from the control value. These findings suggest the occurrence of abnormal tubular permeability and back-diffusion probably associated with tubular damage resulting from the 
hemolysate administration. The 50 per cent decrease in $E_{\text {hipp }}$ and $E_{\text {cr }}$ that occurred in dog 11 (Table V) is compatible with this explanation, especially in view of the absence of a change in RBF (Table IV).

Histologic changes in the kidneys. An autopsy was performed on all the animals. Grossly, the kidneys showed no striking changes; a moderate degree of congestion and hyperemia appeared to be present, and the corticomedullary markings were somewhat accentuated. Microscopically, the kidneys showed varying degrees of tubular damage with minimal changes in the glomeruli. The tubular changes were similar to those seen characteristically in human acute renal failure with tubular necrosis. These ranged from cytoplasmic vacuolization in the tubular epithelial cells to frank necrosis and desquamation into and obliteration of the tubular lumina. These latter changes were predominantly in the proximal tubules. In general, the intensity of tubular damage appeared to be relative to the degree of functional changes in each animal. Pale-staining pink proteinaceous material was seen in the lumina of many tubules. In the distal tubules and collecting ducts, casts were observed that stained positively with alizarin red, a stain for hemoglobin. The limitations of drawing mechanistic conclusions from sections prepared by routine histologic techniques are obvious. Individual nephron dissection was not performed.

\section{DISCUSSION}

Severe renal ischemia has been assumed to play a major role in both the initiation and the maintenance of the oliguria of acute renal failure (22, 23). Bull, Joekes, and Lowe (24) and Sirota (25), using the direct Fick-PAH technique, concluded that RPF was extremely low during the late oliguric and early diuretic phases of acute tubular necrosis. However, Conn, Wilds, and Helwig (7), Brun and colleagues (15), Munck (16), and Meriel, Galinier, and Suc (26), employing the gas diffusion method to study RBF, demonstrated in both dogs and humans with severe oliguria that $\mathrm{RBF}$ was not negligible, but 30 to 50 per cent normal in most studies. These flows are compatible with considerable glomerular filtration. Two patients during oliguria had normal blood flow values $(15,26)$. Using krypton ${ }^{85}$, we have observed a normal $\mathrm{RBF}$ in a patient with oliguric acute renal failure after a hemolytic transfusion reaction (27).

The administration of autologous hemolyzed cells, hemoglobin, or distilled water intravenously has been shown to result in a reduction in $\mathrm{V}$ and in $C_{\text {PAII }}(8-12)$. Because $E_{P A H}$ did not change with lower values for $\mathrm{C}_{\mathbf{P A H}}(8,9)$, the latter was taken to be a valid measurement of effective RPF. The possibility, however, of intrarenal storage or retention of the substances used for clearance measurements was not ruled out. Also, the interpretation of data derived from clearance measurements obtained during periods of very low $\mathrm{V}$ is subject to many limitations $(28,29)$.

Because reports of measurements of RBF during pigment excretion by methods not dependent on urine collections are scarce (2), the present study was performed. The results indicate that the changes in renal function after the administration of hemolyzed cells are not associated with a decrease in RBF per unit weight of kidney tissue. If acute oliguria can occur without evidence of severe renal ischemia, then one must consider other possible explanations for the observed changes.

Intrarenal shunts and focal ischemia. The actual flow values derived from the gas diffusion method would not reflect the possible occurrence of gross arteriovenous shunting of blood (30) with maintenance of the perfusion: tissue weight ratio. Under these conditions, however, although the values might be similar for the control and postinfusion flows, shunting would be indicated by other characteristics of the experimental data. In order for the control and postinfusion values for blood flow to be the same, the area between the arterial and renal venous curves of $\mathrm{Kr}^{85}$ concentration would have to be the same for both determinations, since $R^{t}$ and $S$ would not change. Shunting would be manifested by an alteration in the configuration of the curves in that the venous curve would at all times be closer to the arterial curve in the postinfusion flow determination; therefore, in order to maintain the same area between the curves, the time required for tissue: blood equilibrium would have to be longer than the control flow. As seen in Figures 1 and 2. these changes did not occur in $\operatorname{dog} 7$, nor were they 
seen in any of the other animals in which $\mathrm{RBF}_{\mathbf{K r}}$ was measured.

Further evidence against shunts lies in the data on $(A-R) \mathrm{O}_{2}, \mathrm{E}_{\text {hipp }}, \mathrm{E}_{\mathrm{PAH}}$, and $\mathrm{E}_{\mathrm{cr}}$. The preservation of the control values for these variables or the absence of a consistent decrease during the periods of decreased $\mathrm{V}$ indicates the absence of any significant arterializing shunts.

Although generalized renal ischemia did not appear to have occurred following the infusion of hemolysate, it is conceivable that cessation of perfusion to focal areas of the kidney may have resulted from the procedure. For example, if half of the kidney had been rendered markedly or totally ischemic and if the flow to the remaining half had doubled (assuming the krypton would still gain access to the ischemic portion by diffusion), then the values for $R_{B F}$ Kr would not change significantly. This possibility has not been conclusively ruled out. It is felt however, to be unlikely because 1 ) there was no evidence of prolongation of the time required for tissue: blood equilibrium that ought to have occurred if a large portion of the kidney were not perfused, and 2) gross and histological examination of the kidneys either shortly after the acute experiments or several hours later showed no evidence of focal ischemia.

If intrarenal shunts, decreased renal extraction, or focal ischemia do not account for the decreased clearances, then the validity of direct Fick or clearance methods in situations associated with the excretion of blood pigments may be questioned. One of the assumptions necessary for the application of the Fick equation $R P F=U V / A-R$ is that the bladder urine, from which the $U V$ is determined, contains all of the test substance which has been extracted from the blood by the kidney. It is possible that this basic assumption under these conditions may not be applicable and that changes in $\mathrm{C}_{\text {hipp }}$ do not necessarily reflect alterations in $\mathrm{RBF}$.

Abnormal tubular permeability and back-diffusion of the glomerular filtrate. A discrepancy between clearance estimates and direct measurements of RBF under conditions of reduced RBF and low $\mathrm{V}$ has been demonstrated by Selkurt (31), Study and Shipley (32), and more recently by Balint (33). Selkurt (31) concluded that abnormal tu- bular permeability and back-diffusion explained the decrease in $\mathrm{C}_{\mathrm{PAH}}$ and $\mathrm{C}_{\mathrm{cr}}$ out of proportion to changes in direct hemodynamic measurements. This was based on the occurrence of clecreased $\mathrm{U} / \mathrm{P}$ creatinine as well as decreased $\mathrm{E}_{\mathbf{P A H}}$ in association with oliguria. When RPF was calculated by dividing $\mathrm{C}$ by $\mathrm{E}$, the values for $\mathrm{RBF}$ were in better agreement with the values obtained by direct measurements. What evidence exists for abnormal tubular back-diffusion in our experiments? If it occurred, evidence for decreased renal extraction of various substances ought to have been observed ; as already discussed, no consistent manifestations of it were present. In dog 11 , however, a 50 per cent decrease in $\mathrm{E}_{\text {hipp }}$ and $\mathrm{E}_{\mathrm{cr}}$ occurred after the administration of the hemolysate. These data and the postinfusion fall in $\mathrm{U} / \mathrm{P}$ creatinine and $\mathrm{U} / \mathrm{P}$ osmolality do, in fact, suggest back-diffusion of hippuran and creatinine and osmotic equilibration of the glomerular filtrate with plasma. A marked decrease in $\mathrm{U} / \mathrm{P}$ creatinine suggesting tubular damage and increased permeability was also present in dogs 5 and 6 . In the remainder of the experiments, however, i.e., in three fourths of the animals, there was a definite increase in $\mathrm{U} / \mathrm{P}$ creatinine and $\mathrm{U} / \mathrm{P}$ osmolality, suggesting relative intactness of tubular impermeability to creatinine and the ability to maintain or increase the $\mathrm{U} / \mathrm{P}$ osmotic gradient. The rise in the $\mathrm{U} / \mathrm{P}$ osmotic ratio could be explained by factors other than antidiuretic hormone, such as a very slow rate of $\mathrm{V}$ in the distal nephron and collecting ducts (34).

Primary glomerular damage with reduced GFR. Evidence that reduction in glomerular filtration was not the initial event in the series of changes resulting from the infusion of the hemolysate is 1) the absence of histologic changes in the glomeruli in the presence of marked tubular abnormalities and 2) the absence of a consistent change in $E_{\text {cr }}$ in the presence of unchanged RBF during the first 2 hours after the infusion of hemolysate. Although GFR might have decreased, the data suggest that, initially, the fall was not so great as the decrease in $\mathrm{C}_{\mathrm{er}}$ indicates.

Intratubular obstruction. In 1947, Harrison, Bunting, Ordway, and Albrink (2) produced oliguria and azotemic renal failure in dogs by the administration of large doses of hemoglobin and 
methemoglobin intravenously and by the use of arsine gas, which causes intravascular hemolysis and hemoglobinuria. The abnormalities were more likely to occur if the $V_{c}$ were extremely low from dehydration. By a direct cannulation technique, $\mathrm{RBF}$ was measured in 2 animals before and after infusions of methemoglobin. In both, RBF did not fall acutely, despite the production of virtual anuria in one of the animals. The authors concluded that obstruction to $\mathrm{V}$ through the renal tubules was an important factor in the early reduction of kidney function. The material filling the lumina of the renal tubules was found to be chiefly methemoglobin in concentrated solution of gel-like consistency.

The hypothesis of intratubular obstruction is consistent with our own experimental data, and the results of our studies are compatible with the conclusions of the authors above. RBF data in 7 animals demonstrated the absence of renal ischemia even in the presence of severe oliguria. A change in the physicochemical properties of the intratubular contents related to the excretion of the products of hemolysis may produce an increase in intratubular viscosity, which in turn may impede the flow of urine and result in complete or partial obstruction in many nephrons. Under these conditions, despite substantial renal perfusion and glomerular filtration in the early stages, $\mathrm{V}$ is so diminished that progressively more of the glomerular filtrate, particularly sodium and water, is reabsorbed. This is a self-perpetuating process in that increased water reabsorption produces increased $\mathrm{U} / \mathrm{P}$ ratios of various urinary substances, including protein. The increasing protein concentration may further increase intratubular viscosity and facilitate protein precipitation and cast formation. As tubular obstruction becomes more complete and prolonged, glomerular filtration would eventually be expected to decrease markedly.

The fact that decreases in $\mathrm{C}_{\text {cr }}$ appeared to be more severe at lower $V_{c}$ is also compatible with the hypothesis above. The lower the intratubular urine volume at the time of excretion of various blood pigments, the higher the concentration of the latter and therefore the more likely that the viscosity will increase. At higher $V_{c}$ the increase in urinary viscosity is only moderate and thus only partial or incomplete obstruction develops, or fewer nephrons are completely obstructed, but at lower initial flows there is more complete obstruction, and considerably less of the filtered creatinine reaches the bladder urine.

This interpretation would not preclude the simultaneous occurrence of direct tubular damage if the concentration of certain toxic substances was high enough or if the time of exposure of the tubules to the toxins was long enough. Histologic evidence of tubular damage of varying severity was present in all of our experiments. As pointed out by Oliver, MacDowell, and Tracy (35), the combination of tubular obstruction with abnormal tubular permeability would enhance the passage of urine from the tubular lumen into the interstitial space and ultimately back into the circulation. In three experiments, with dogs 5, 6, and 11, "nonselective" tubular reabsorption may have played a significant role. In the remainder, however, tubular selectivity appeared to remain relatively intact, at least in regard to the maintenance of $U / P$ concentration gradients for creatinine and total solute.

The importance of the actual volume flow of urine at the time of blood pigment excretion for determination of the degree of renal impairment has been observed by others $(1,2,4)$. Moreover, the mitigating effects of osmotic diuresis with mannitol have also been described (4); it may serve to retard tubular water reabsorption and thus to prevent a marked rise in urinary protein concentration and an increase in urinary viscosity. Alterations in renal hemodynamics may significantly contribute to the production of acute renal failure associated with pigment excretion when they are great enough to affect urine flow.

\section{SUM MARY}

The intra-aortic administration of homologous hemolyzed red blood cells to dogs resulted in acute decreases in urine flow, creatinine clearance, and hippuran clearance. Despite these changes, generalized decreases in renal blood flow measured by a gas diffusion technique using krypton ${ }^{85}$ did not occur. Consistent changes in renal arteriovenous oxygen difference and the renal extraction of hippuran, creatinine, and para-aminohippurate were absent. In most animals, decreases in urine flow were associated with increases in urine/ plasma creatinine and osmolality. In a few ex- 
periments, oliguria was associated with decreased urine/plasma creatinine and osmolality and decreased renal extraction of hippuran and creatinine.

It is concluded that the administration of hemolyzed red blood cells may produce acute alterations in renal function that are unrelated to generalized renal ischemia, hypoxemia, or the occurrence of gross intrarenal shunts. The changes appear to be secondary to intratubular obstruction and concomitant toxic tubular damage.

\section{ACKNOWLEDGMENTS}

The author is indebted to Drs. Lewis W. Bluemle, Jr., and Hadley L. Conn, Jr. for their helpful advice and encouragement throughout the course of these experiments, especially in regard to the numerous technical problems that arose; to Dr. J. Russell Elkinton for his support and for helpful criticisms of the manuscript; and to Dr. Arnold J. Rawson for reviewing some of the pathological slides. Invaluable technical assistance was provided by Miss A. J. Langsdale and Mr. James Mitchell, and chemical analyses were performed by Mrs. Lidia Kosolapovs and Mrs. Katherine Wishnevski. The author wishes to thank Dr. Earle S. Barker for the PAH determinations and Dr. John Helwig for use of his laboratory for the oxygen determinations.

\section{REFERENCES}

1. Maluf, N. S. R. Factors inducing renal shut-down from lysed erythrocytes: an experimental study. Ann. Surg. 1949, 130, 49.

2. Harrison, H. E., Bunting, H., Ordway, N. K., and Albrink, W. S. The pathogenesis of the renal injury produced in the dog by hemoglobin or methemoglobin. J. exp. Med. 1947, 86, 339.

3. Weiner, R. S., Finkenstaedt, J. T., Rosoff, C. B., Jessiman, A. C., and Walter, C. W. Renal function studies in the dog, following the production of controlled unilateral and bilateral hemoglobinuric nephrosis. Surg. Forum 1951, 2, 353 (Philadelphia, W. B. Saunders, 1952).

4. Owen, K., Desautels, R., and Walter, C. W. Experimental renal tubular necrosis-the effect of pitressin. Surg. Forum 1953, 4, 459.

5. Flink, E. B. Blood transfusion studies. III. The relationship of hemoglobinemia and of the $\mathrm{pH}$ of the urine to renal damage produced by injection of hemoglobin solutions into dogs. J. Lab. clin. Med. 1947, 32, 223.

6. Bing, R. J. The effect of hemoglobin and related pigments on renal functions of the normal and acidotic dog. Johns Hopk. Hosp. Bull. 1944, 74, 161.

7. Conn, H. L., Jr., Wilds, L., and Helwig, J. A study of the renal circulation, tubular function and morphology, and urinary volume and composition in dogs following mercury poisoning and transfu- sion of human blood. J. clin. Invest. 1954, 33 , 732.

s. Miller, J. H., and McDonald, R. K. The effect of hemoglobin on renal function in the human. $\mathrm{J}$. clin. Invest. 1951, 30, 1033.

9. Brandt, J. L., Frank, N. R., and Lichtman, H. C. The effects of hemoglobin solutions on renal functions in man. Blood 1951, 6, 1152.

10. Blackburn, C. R. B., Hensley, W. J., Grant, D. K., and Wright, F. B. Studies on intravascular hemolysis in man. The pathogenesis of the initial stages of acute renal failure. J. clin. Invest. 1954, $33,825$.

11. Lowenstein, J., Faulstick, D. A., Yiengst, M. J., and Shock, N. W. The glomerular clearance and renal transport of hemoglobin in adult males. J. clin. Invest. 1961, 40, 1172.

12. Demaria, W. J. A., and Harris, J. S. Effect of magnesium sulfate on the alterations in renal dynamics induced by intravenous hemoglobin. Amer. J. Physiol. 1955, 182, 251.

13. Kety, S. S., and Schmidt, C. F. The nitrous oxide method for the quantitative determination of cerebral blood flow in man: theory, procedure and normal values. J. clin. Invest. 1948, 27, 476.

14. Conn, H. L., Jr., Anderson, W., and Arena, S. Gas diffusion technique for measurement of renal blood flow with special reference to the intact, anuric subject. J. applied Physiol. 1953, 5, 683.

15. Brun, C., Crone, C., Davidsen, H. G., Fabricus, J., Hansen, A. T., Lassen, N. A., and Munck O. Renal blood flow in anuric human subject determined by use of radioactive krypton 85 . Proc. Soc. exp. Biol. (N. Y.) 1955, 89, 687.

16. Munck, O. Renal Circulation in Acute Renal Failure. Oxford, Blackwell Scientific Publications, 1958.

17. Bonsnes, R. W., and Taussky, H. H. On the colorimetric determination of creatinine by the Jaffe reaction. J. biol. Chem. 1945, 158, 581.

18. Smith, H. W., Finkelstein, N., Aliminosa, L., Crawford, B., and Graber, M. The renal clearances of substituted hippuric acid derivatives and other aromatic acids in dog and man. J. clin. Invest. 1945, 24, 388.

19. Snedecor, G. W. Statistical Methods, 5th ed. Ames, Iowa, Iowa State College Press, 1956, pp. 190-192.

20. Burbank, M. K., Tauxe, W. N., Maher, F. T., and Hunt, J. C. Evaluation of radioiodinated hippuran for the estimation of renal plasma flow. Staff Meet. Mayo Clin. 1961, 36, 372.

21. Goldberg, M., Barker, E. S., and Sigler, M. H. The renal extraction and red blood cell penetration of radioiodinated hippuran in dogs. In preparation.

22. Smith, H. W. Acute renal failure. Kaiser Fdn med. Bull. 1958, 6, 18.

23. Franklin, S. S., and Merrill, J. P. Acute renal failure. New Engl. J. Med. 1960, 262, 711, 761. 
24. Bull, G. M., Joekes, A. M., and Lowe, K. G. Renal function studies in acute tubular necrosis. Clin. Sci. 1950, 9, 379.

25. Sirota, J. H. Carbon tetrachloride poisoning in man. I. The mechanisms of renal failure and recovery. J. clin. Invest. 1949, 28, 1412.

26. Meriel, P., Galiner, F., and Suc, J. M. Le débit sanguin rénal dans les états de choc. Proceedings, First International Congress of Nephrology (1960), Basel, S. Karger, 1961, 224.

27. Goldberg, M., Bluemle, L. W., Jr., Conn, H. L., and Helwig, J. Unpublished observations.

28. Phillips, R. A., Dole, V. P., Hamilton, P. B., Emerson, K., Jr., Archibald, R. M., and Van Slyke, D. D. Effects of acute hemorrhagic and traumatic shock on renal function of dogs. Amer. J. Physiol. 1946, 145, 314.

29. Smith, H. W. Note on the interpretations of clearance methods in the diseased kidney. J. clin. Invest. 1941, 20, 631 .

30. Trueta, R. J., Barclay, A. E., Daniel, P. M., Franklin, K. J., and Prichard, M. M. L. Studies of the renal circulation. Springfield, Ill., Charles C Thomas, 1947.

31. Selkurt, E. E. Renal blood flow and renal clearance during hemorrhagic shock. Amer. J. Physiol. 1946, 145, 699.

32. Study, R. S., and Shipley, R. E. Comparison of direct with indirect renal blood flow, extraction of inulin and diodrast, before and during acute renal nerve stimulation. Amer. J. Physiol. 1950, 163, 442.

33. Balint, P. Le flux sanguin rénal au cours de l'hypotension et de l'hypobolémie expérimentales. Proceedings, First International Congress of Nephrology, Basel, S. Karger, 1961, 207.

34. Berliner, R. W., and Davidson, D. G. Production of hypertonic urine in the absence of pituitary antidiuretic hormone. J. clin. Invest. 1957, 36, 1416.

35. Oliver, J., MacDowell, M., and Tracy, A. The pathogenesis of acute renal failure associated with traumatic and toxic injury. Renal ischemia, nephrotoxic damage and the ischemuric episode. J. clin. Invest. 1951, 30, 1307. 